\title{
5-Azacytidine Promotes Differentiation of Bone Marrow Derived Mesenchymal Stem Cells into Troponin Positive Cardiomyocyte-Like Cells in Vitro.
}

\author{
Iman A.Ahmedy ${ }^{1}$ MD, Waleed M. Fathy ${ }^{2}$ MD, Rasha I.Noreldin ${ }^{3}$ MD. Wassam \\ EL Din Elshafey ${ }^{4} \mathrm{MD}$ \\ ${ }^{I}$-Department of clinical pathology, faculty of Medicine, Menoufia University. Shebin EL Kom, Menoufia, Egypt \\ ${ }^{2}$-Department of clinical pathology, faculty of Medicine, Menoufia University. Shebin EL Kom, Menoufia, Egypt. \\ ${ }^{3}$-Department of clinical pathology, faculty of Medicine, Menoufia University. Shebin EL Kom, Menoufia, Egypt \\ ${ }^{4}$ Department of Cardiology, faculty of Medicine, Menoufia University, Shebin EL Kom, Menoufia, Egypt
}

\begin{abstract}
Objective: The aim of this work is to differentiate Mesenchymal stem cells derived (MSCs) from bone marrow obtained from human adult into cardiomyocyte using 5-azacytidine in vitro.

Background: MSCs are considered a promising tool for cellular therapy because of their capability for selfrenewing and their multipotency. Owing to the limited ability of the injured heart to regenerate cardiomyocytes. Cardiomyocyte transplantation has been advocated as a possible treatment for heart failure. Their other benefits on a myocardiac infarct is owed to neo-vascularization, because they can differentiate also into endothelial cells.
\end{abstract}

Methods: MSCs were cultured from bone marrow aspirate and detected morphologically and by flowcytometric analysis of surface markers CD44 and CD 34 then differentiated to cardiomyocytes by using 5azacytidine. The cardiomyocytes were detected morphologically and by flowcytometric analysis of Vimentin and Troponin and immunofluorescence analysis for Cardiac alpha tropomyosin

Results: MSCs can be isolated from bone marrow and assumed the typical fibroblastoid morphology and reach 80\% - 90\% confluence at about 9 days. They express CD44 and are negative for CD 34 .MSCs induced with 5azacytidine show morphological changes consistent with cardio myocytes as compared to the symmetric morphologies of the uninduced cells, as shown by inverted microscope. Induced cells showed positive expression of troponin and vimentin and positive cardiac alpha tropomyosin..

Conclusion: MSCs can be successfully isolated from bone marrow aspirate and can be differentiated into cardiomyocytes.

Key words; ; 5-azacytidine,cardiac alpha tropomyosin, cardiogenesis, mesenchymal stem cells, troponin

\section{Introduction}

Mesenchymal stem cells (MSCs) are considered a promising tool for cellular therapy because of their capability for self-renewing and their multipotency .They were discovered by Friedenstein from cultures of bone marrow cells and suggested to be stromal cells [1]. Others have studied the properties and multipotency of these bone marrow cells in human [2]. They possess the following characters : plastic adherence; positive expression of CD105, CD90, and CD44; and a differentiation ability into a mesodermal lineage e.g. adipogenic, , chondrogenic and osteogenic cells [3] . MSCs show promising future for their variable uses in medical field owing to their unique self-renewing ability and there differentiation potential into different cell types[4]. In earlier days, MSCs was regarded that their differentiation is restricted only to few cell types such as chondrocytes ,adipocytes and osteocytes[5]. While recent studies have proven their differentiation ability into cell types of all three lineages including cardiomyocytes[6]. It has been suggested that the heart has a relatively stable but slowly decreasing number of myocytes soon after birth to adulthood and senescence [7]. Myocardial Infarction (MI) is one of the leading causes of mortality all over the world owing to constant changes in lifestyle with increasing stress [8]. MI is due to blood supply shortage to a part of the heart reducing the oxygenation of the affected area resulting in its necrosis (scar formation) and no complete recovery [9].

It was also revealed that transplanted fetal cardiomyocytes could survive in the scar tissue, limiting scar expansion and preventing post infarction heart failure. The cardiomyocytes transplantation into the damaged myocardium has been proposed as a future method for heart failure treatment [10]. Although several types of progenitor cells may be appropriate for cell-based tissue repair in patients with heart failure [11] multipotent 
MSCs obtained from the bone marrow are very attractive because of their easy extraction and expansion in culture[12]. The other benefits of bone marrow MSCs transplantation on a myocardial infarct is due to neovascularization, because they tend to differentiate into endothelial cells[13-15]. and they have immunosuppressive properties which help inhibition of proliferation and function of major immune cells as $\mathrm{T}$ cells, B cells, and NK cells[16].

\section{Aim Of The Study}

The aim of this study is in vitro differentiation of MSCs separated from bone marrow obtained from adult human into cardiomyocyte by the use of 5 - azacytidine.

\subsection{Culture of MSCs:}

\section{Materials And Methods}

The present study was held in the Clinical Pathology Department, El- Menoufia University Hospital. Bone marrow sample was aseptically collected from patients after obtaining their consent according to Institutional Review Board. It was diluted with sterile PBS (Invitrogen) and layered on top of ficoll-hypaque(Biochrom AG ). The MNC fraction was collected and seeded at a concentration of $\left(\right.$ million cells $/ \mathrm{cm}^{2}$ ) and allowed to adhere to tissue culture plastic flasks $25 \mathrm{~cm}^{2}$ (cell star), incubated at $37 \mathrm{C}$ and $5 \% \mathrm{CO} 2 \mathrm{in} 5 \mathrm{ml}$ of the fresh complete nutrient medium (F10 media) which was constituted of the following: Low-glucose DMEM (Dulbecco's modified Eagle's Medium) with L-glutamine (2mmol/L)(sigma),10\% FBS (Fetal bovine serum) (Euroclone)., Penicillin- streptomycin $(100 \mathrm{U} / \mathrm{ml}$ penicillin and $100 \mu \mathrm{g} / \mathrm{ml}$ streptomycin and $0.25 \mu \mathrm{g} / \mathrm{mL}$ Fungizone (Bioscience), basic fibroblast growth factor bFGF and Insulin-like Growth Factor I (IGF-I) $10 \mathrm{ng} / \mathrm{ml},(R \& D$ system). Half medium was changed every 4 days for removal of non-adherent cells. At day 9 , when fibroblastlike cells reach 80-90\% confluence, these cells were harvested by trypsinization (Trypsin EDTA 0.25\% Lonza). The cells were detected before differentiation by flow cytometer (Beckman Coulter Inc,) for antigen marker of MSCs by Phycoerythrin (PE) anti-human CD44(Beckman Coulter), and that of hemopoietic stem cells by Phycoerythrin (PE) anti-human CD34(Beckman Coulter). For surface antigens expression, $20 \mu \mathrm{L}$ of corresponding antibody was added to $1 \times 10^{6}$ mononuclear cells $(100 \mu \mathrm{L})$ followed by 15 min incubation. Then $2 \mathrm{~mL}$ lysing solution (1:10 dilution, BD Biosciences) was added to the samples followed by $15 \mathrm{~min}$ incubation. Samples centrifugation at $400 \mathrm{~g}$ for $5 \mathrm{~min}$ was done. The pellet was washed twice with (PBS) and resuspended in $500 \mu \mathrm{L}$ PBS. Simultaneous staining of surface antigens isotype controls were done.

\subsection{Cardio myogenic Differentiation of MSCs:}

Around $1 \times 10^{4}$ of MSCs were seeded in $35 \mathrm{~mm}$ culture dishes .Cells were treated with $10 \mu \mathrm{M} 5$-azacytidine (Sigma-Aldrich Co.,) on the second day after seeding .Media was changed every 3 days. The cells differentiation take a period of 12 days. Morphological changes by inverted and phase contrast microscope were observed every day.

\subsection{Flowcytometric detection of Vimentin and Troponin $T$ in cardiomyocytes:}

Samples were prepared for surface flow cytometric detection of vimentin by Phycoerythrin (PE) antihuman Vimentin (cell signaling technology inc.) and for intracytoplasmic detection of troponin by Phycoerythrin (PE) anti-human troponin $\mathrm{T}(R \& D$ system) (fixation and permeability reagent purchased from Beckman coulter).Surface makers were studied as described previously. For cytoplasmic antigen expression, $2 \mathrm{~mL}$ lysing solution (1:10 dilution, BD Biosciences) was added to $1 \times 10^{6}$ mononuclear cells $(100 \mu \mathrm{L})$ followed by $15 \mathrm{~min}$ incubation. Samples centrifugation at $400 \mathrm{~g}$ for $5 \mathrm{~min}$ was done. $1 \mathrm{~mL}$ Perm/Wash buffer $(1: 10$ dilution, BD Biosciences) was added to the pellet followed by $20 \mathrm{~min}$ incubation. Samples centrifugation at $400 \mathrm{~g}$ for $5 \mathrm{~min}$ was done then the supernatant was discarded. The corresponding antibody $(20 \mu \mathrm{L})$ was added then followed by $15 \mathrm{~min}$ incubation. Then $2 \mathrm{~mL}$ PBS was added. Samples centrifugation at $400 \mathrm{~g}$ for $5 \mathrm{~min}$ was done. The pellet was resuspended in $500 \mu \mathrm{L}$ PBS. Simultaneous staining of surface antigens isotype controls were done.

\subsection{Cardiac alpha Tropomyosin immunofluorescence staining:}

Cells grown on glass coverslips then fixed with $0.5 \mathrm{~mL} 4 \%$ paraformaldehyde in PBS at room temperature for 20 minutes. Then they were washed with $0.5 \mathrm{~mL}$ of $1 \% \mathrm{FBS}$ in PBS three times for 5 minutes each. Then they were permeabilized and blocked with $0.5 \mathrm{~mL}$ of $0.3 \%$ Triton X-100, $1 \%$ FBS serum in PBS at room temperature for 45 minutes. The cells were then incubated with $300 \mathrm{uL} /$ plate of $1 \mathrm{X}$ mouse monoclonal anti-sarcomeric tropomyosin (1:200; Sigma-Aldrich); overnight at $2-8^{\circ} \mathrm{C}$ in the dark. The cells were then washed again three times then incubated with $300 \mathrm{uL} /$ well of secondary antibody at room temperature, in the dark for 60 minutes. Finally the cells were washed three times and the cover slips removed and mounted down on glass slides ready for microscopic observation.

DOI: $10.9790 / 264 X-03030111 \quad$ www.iosrjournals.org $2 \mid$ Page




\subsection{Growth curve analysis}

Proliferation curves will be done for 12 cases. MSCs, MSCs with IGF-1 and cardiomyocytes were studied for the same cases. 10,000 MSCs were seeded in $35 \mathrm{~mm}$ tissue culture dishes and allowed to adhere overnight. The following day, 1/3 of dishes was replaced with F 10 media without I (IGF-I) and containing 10 u 5Azacytidine, another $1 / 3$ of dishes was replaced with F 10 media containing (IGF-I) $10 \mathrm{ng} / \mathrm{ml}$.Every 3-days interval for up to 12 days, the cells were trypsinized and then counted.

\subsection{Morphological examination of MSCs:}

\section{Results}

At day 1 and 2 after the initial plating, the adherent cells show cytoplasmic projections and they form small clusters . The onset of fibroblast can be observed at day $3 \& 4$. At $7^{\text {th }}$ day, cells showed multi-polar fibroblastoid appearance and a $60 \%$ confluence which gradually increased to reach $80 \%-90 \%$ confluence at about 9 days "Fig1\&2".

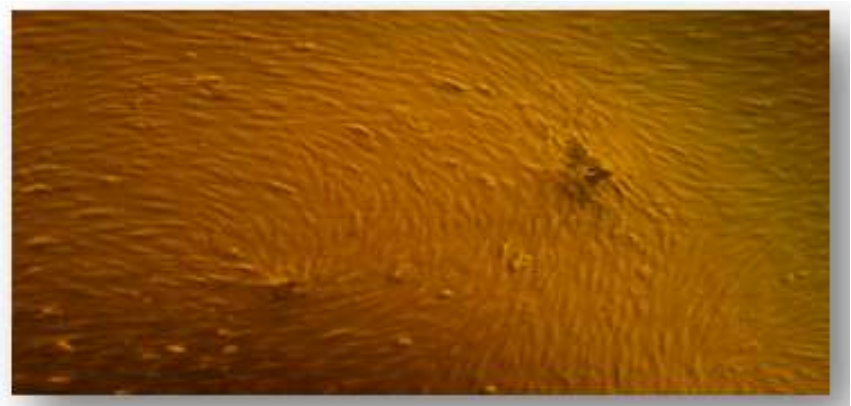

Fig 1: Inverted microscope image x 10 of MSCs with80 -90\% fibroblast confluence

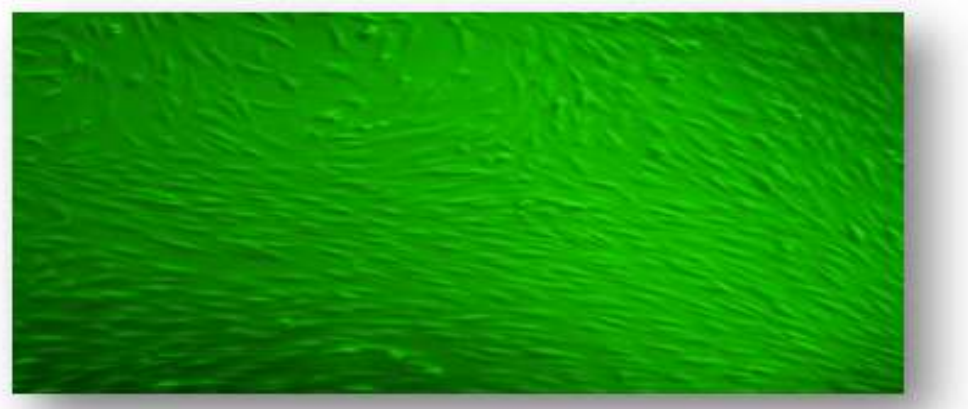

Fig 2: Phase contrast microscope image x 10 of adherent MSCs with $80-90 \%$ fibroblast confluence.

\subsection{Identification of MSCs by flowcytometry :}

MSCs showed positive expression for CD 44 (ranging between 67.10-97.50 with a mean \pm standard deviation of $83.01 \pm 9.55$ ). While they showed negative expression for CD 34 (ranging between 0.10-2.0, with a mean \pm standard deviation of $0.92 \pm 0.55$ )(Fig 3).

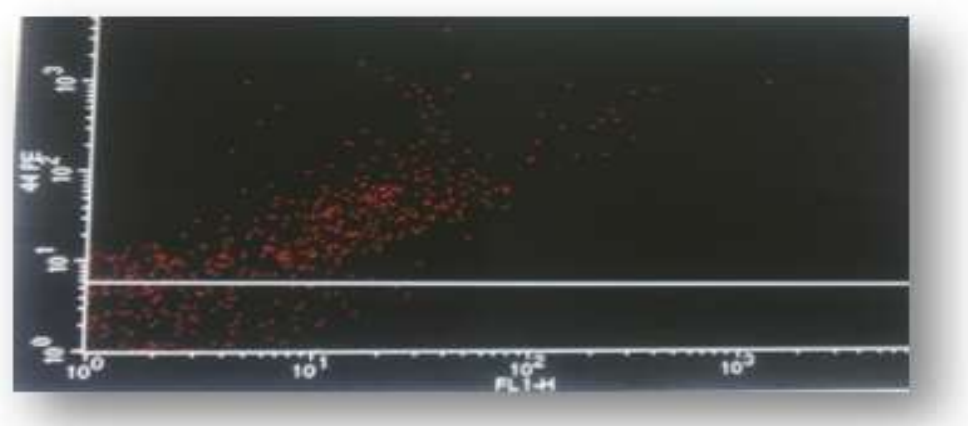

Fig 3: Flowcytometric chart representing positive expression of CD 44 MSCs.

Table 1: Descriptive statistics of flowcytometric results CD34,CD44, on MSCs. Presented as $X \pm S D$, median \& range. 


\begin{tabular}{|r|c|c|}
\hline & \multicolumn{2}{|c|}{ Total(n=30) } \\
\cline { 2 - 3 } & Mean \pm SD & Range \\
\hline CD44 & $83.01 \pm 9.55$ & $67.10-97.50$ \\
\hline CD34 & $0.92 \pm 0.55$ & $0.10-2.0$ \\
\hline
\end{tabular}

\subsection{Morphological changes after cardiogenic differentiation:}

On the $4^{\text {th }}$ day approximately $20-30 \%$ of cells became thinner and aligned parallel to each other "Fig 4" .On the 6th day they were seen in groups of 6-7 cells "Fig5 \&6".They shows central broadening of cytoplasm on the $7^{\text {th }}$ day "Fig $7 \& 8$ " while on the $8^{\text {th }}$ day some of them showed multi nucleation extending their cytoplasmic processes with adjacent cells "Fig 9,10,11". On the $9^{\text {th }}$ day they show ball stick-like morphology "Fig 12,13".

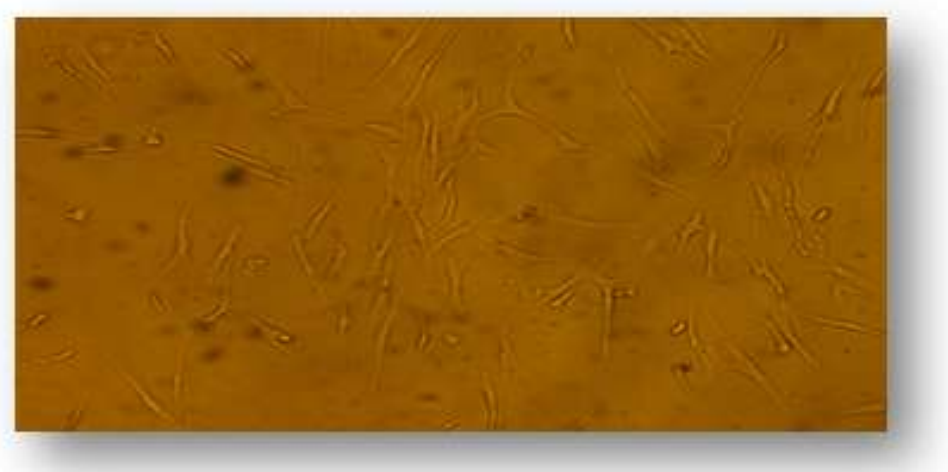

Fig 4: Inverted microscope image $x 10$ of cardiomyocytes, the cells became thinner and aligned parallel to each other $4^{\text {th }}$ day post induction.

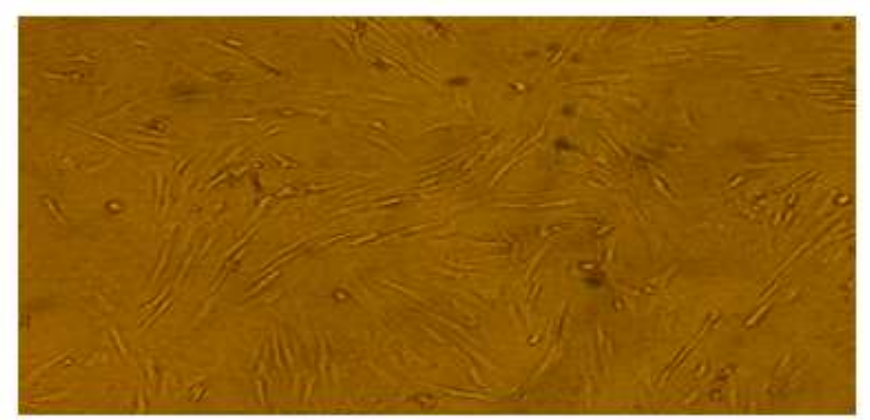

Fig 5: Inverted microscope image $x 10$ of cardiomyocyte on the $6^{\text {th }}$ day post induction, the cells became thinner and arranged in groups.

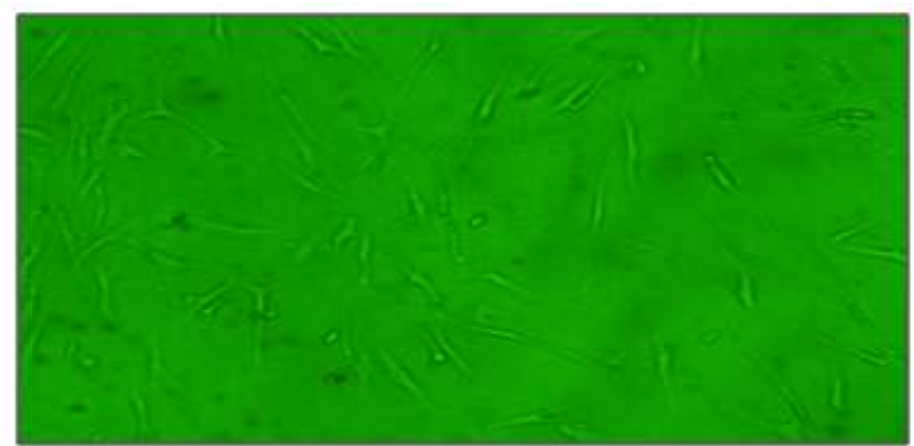

Fig 6: Phase contrast microscopy $x 10$ on the $6^{\text {th }}$ day post induction, the cells became thinner and arranged in groups. 


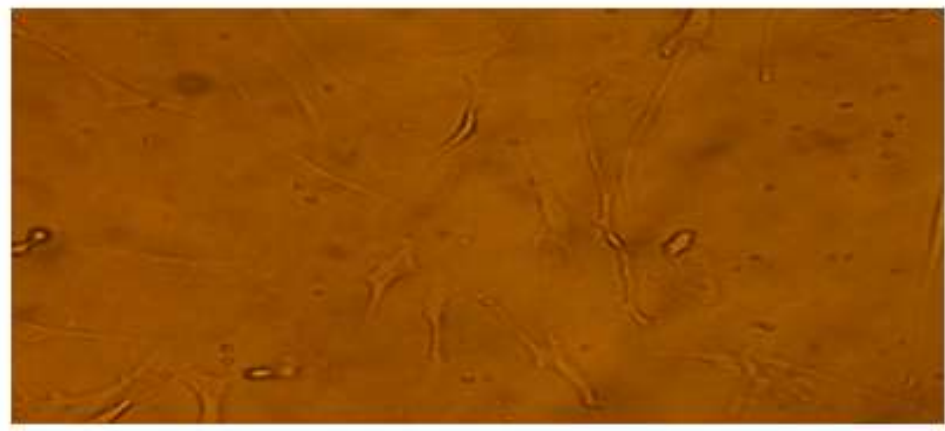

Fig 7: Inverted microscope image $x 20$ of cardiomyocytes on the 7th day post induction showing central broadening of cytoplasm.

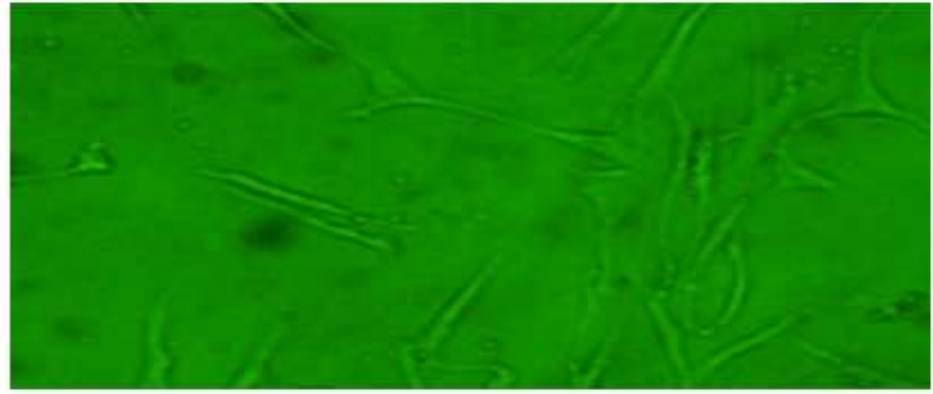

Fig 8: Phase contrast microscopex 20 of cardiomyocytes, on the 7 th day post induction central broadening of cytoplasm.

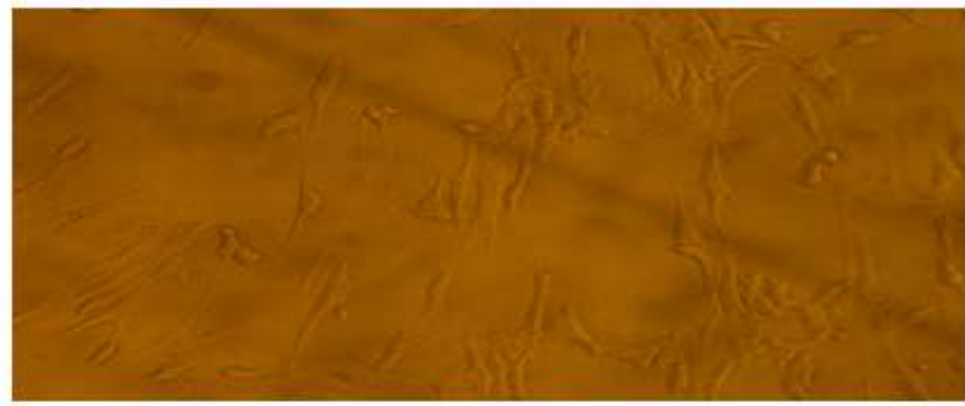

Fig 9: Inverted microscope image $x 20$ of cardiomyocytes, on the 8th day post induction. The cells extended their cytoplasmic processes with adjacent cells.

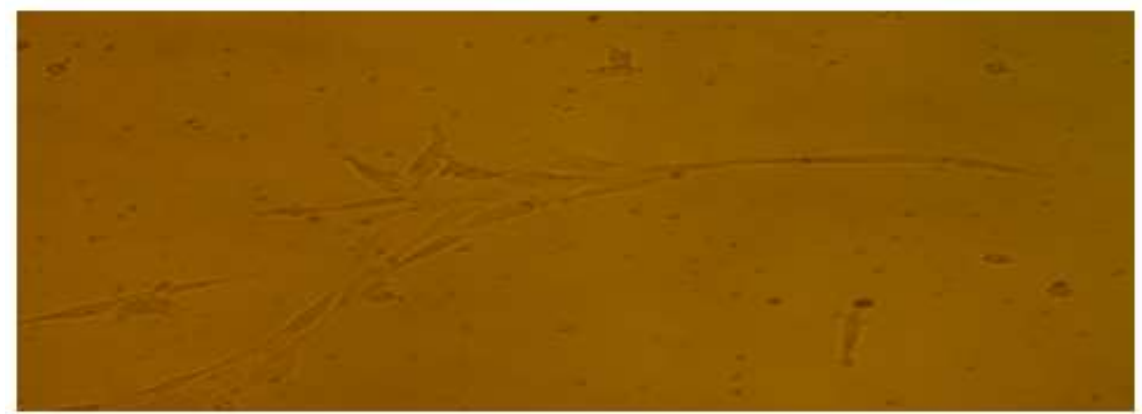

Fig 10: Inverted microscope image $x 20$ of cardiomyocytes, on the 8th day post induction. The cells extended their cytoplasmic processes with adjacent cells. 


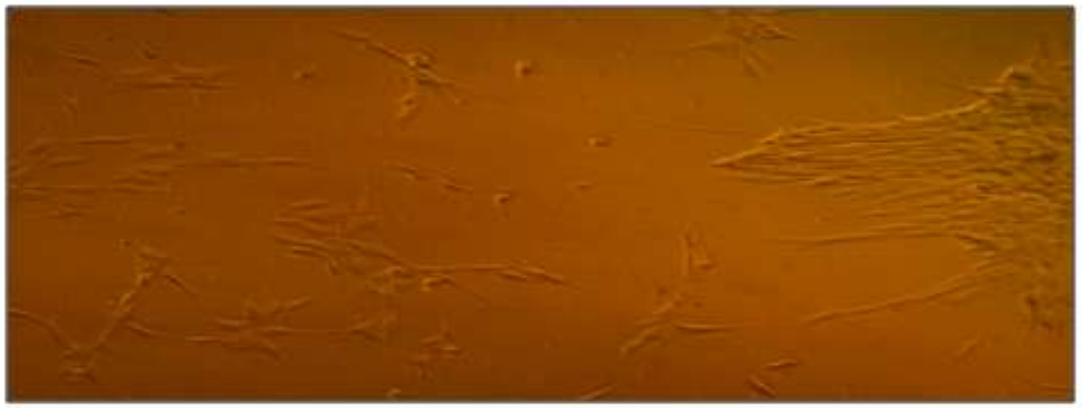

Fig 11: Inverted microscope image x 10 of cardiomyocytes, on the 8th day post induction. The cells extended their cytoplasmic processes with adjacent cells.

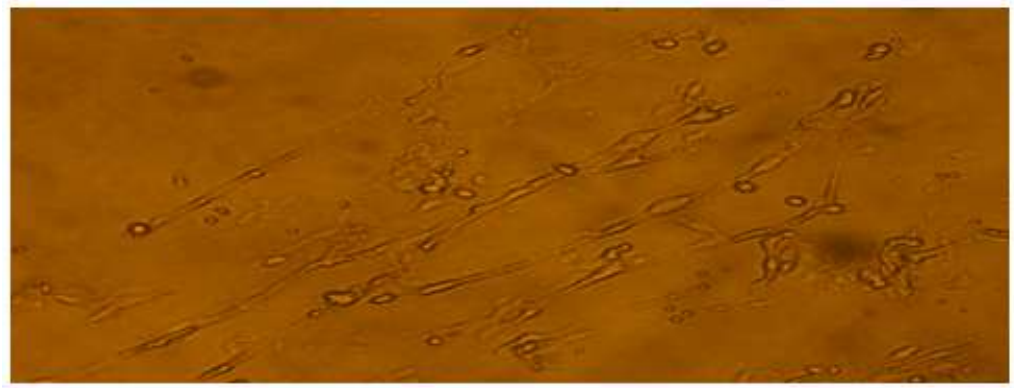

Fig 12: Inverted microscope image $x 20$ of cardiomyocytes, on the 9th day post induction. The cells shows ball stick like morphology.

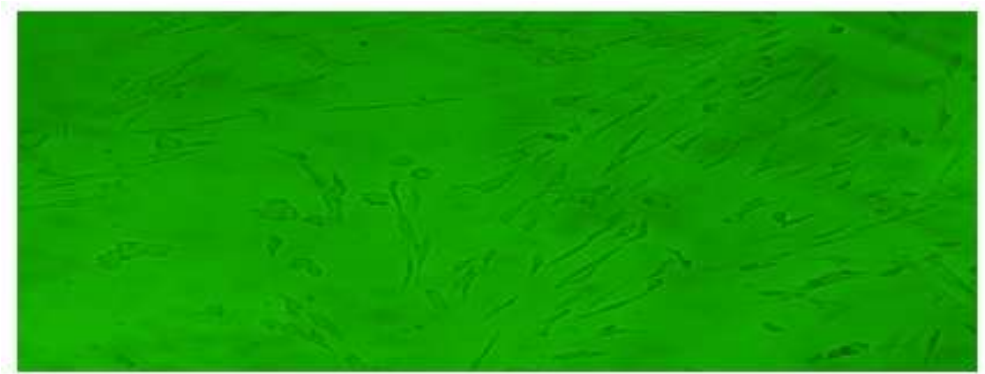

Fig 13: Phase contrast microscope image $x 10$ of cardiomyocytes, on the 9 th day post induction. The cells shows ball stick like morphology.

\subsection{Results of flowcytometric analysis of pre- and post-induction BMA-MSCs:}

MSCs showed low positive expression of vimentin, with a mean \pm standard deviation of 15.18 \pm 4 .11. While cardiomyocytes showed high positive expression of vimentin with a mean \pm standard deviation of $82.46 \pm 9.04$ (Table 1).A highly significant statistical correlation, ( $\mathrm{P}$ value $<0.001$ ) between MSCs and cardiomyocytes vimentin was foundOn the other MSCs showed negative expression of troponin, with a mean \pm standard deviation of $1.23 \pm 0.71$ while cardiomyocytes showed high positive expression of troponin with a mean \pm standard deviation of $71.68 \pm 9.17$ (Table 1). .A highly significant statistical correlation, ( $\mathrm{P}$ value $<0.001$ ) between MSCs and cardiomyocytes troponin was found .

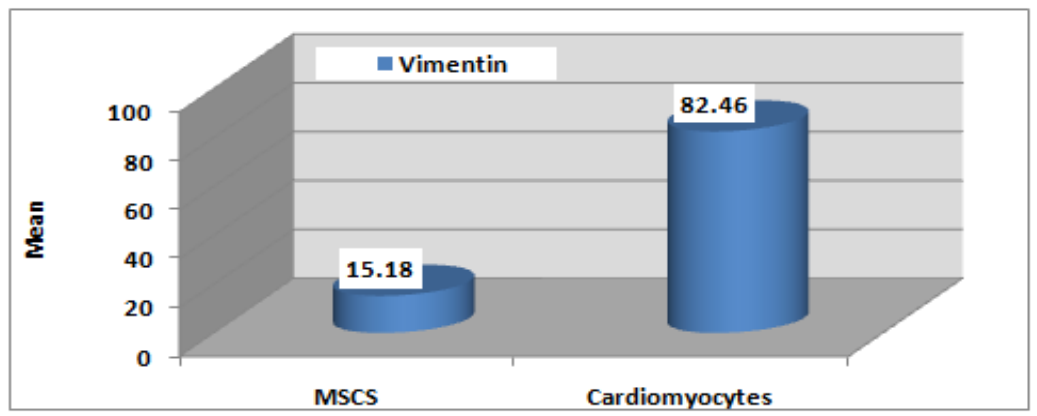

Fig14: Descriptive figures of flowcytometric results of induced and non-induced groups for cardiac Vimentin expression. 


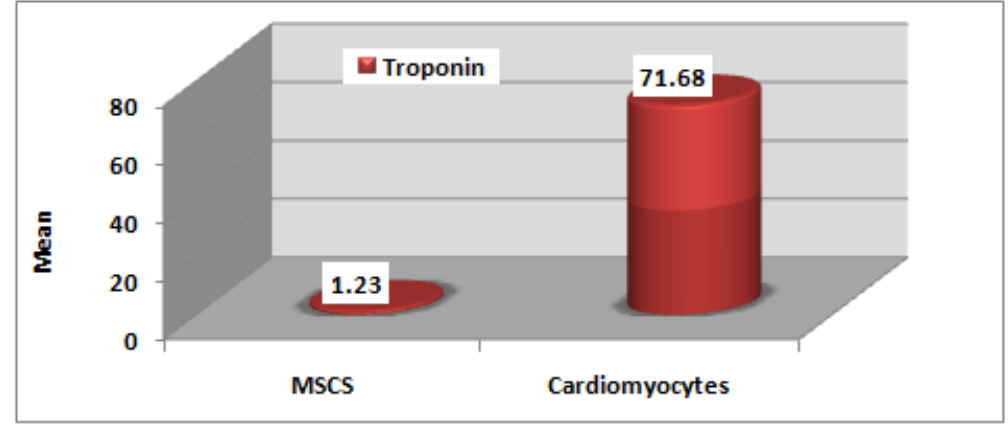

Fig 15: Descriptive figures of flowcytometric results of induced and non-induced groups for cardiac troponin expression.

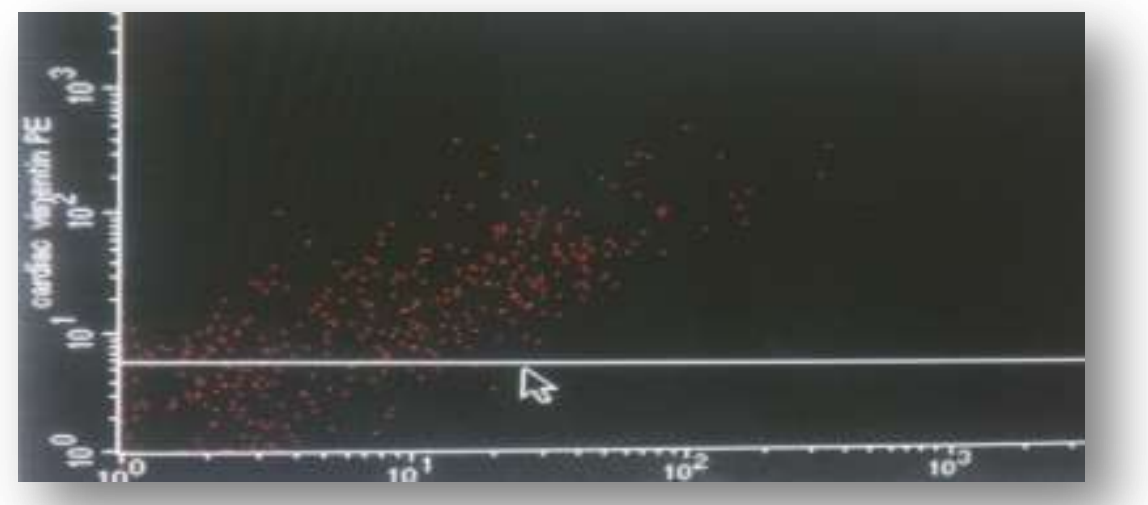

Fig16: Flowcytometric picture representing positive expression of vimentin on cardiomyocytes

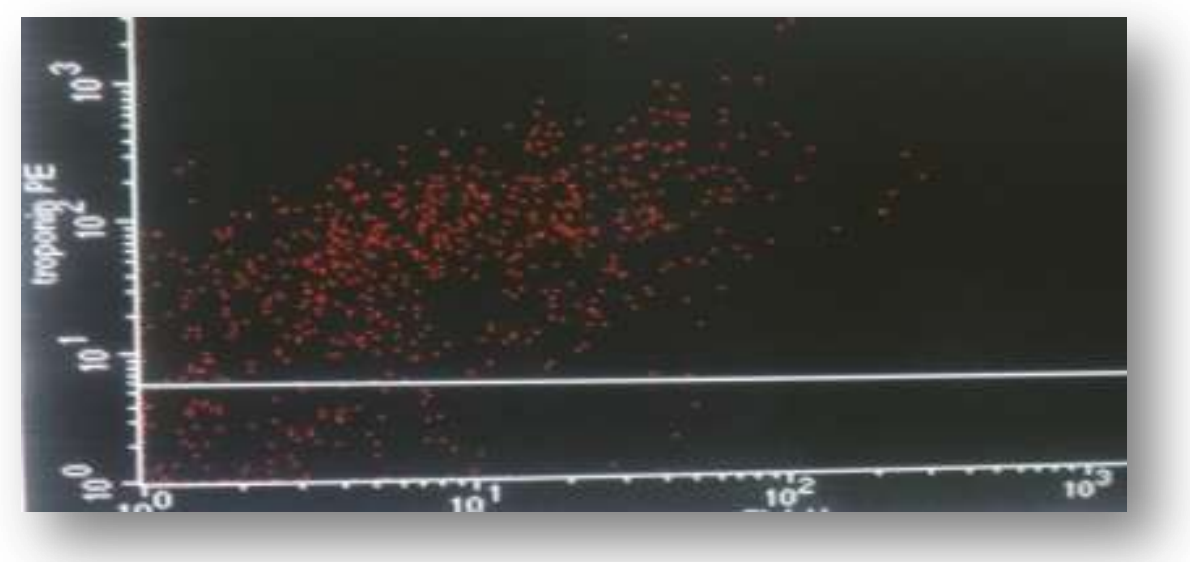

Fig 17: Flowcytometric picture representing positive expression of troponin in cardiomyocytes

Table 2: Descriptive statistics of flowcytometric results of vimemtin amd troponin

\begin{tabular}{|l|c|c|c|c|}
\hline & $\begin{array}{c}\text { MSCS } \\
(\mathbf{n}=30)\end{array}$ & $\begin{array}{c}\text { Cardio } \\
\text { myocytes } \\
(\mathbf{n}=\mathbf{3 0})\end{array}$ & $\begin{array}{c}\text { Test of signi } \\
\text { ficance }\end{array}$ & P value \\
\hline & Mean \pm SD & Mean \pm SD & & \\
\hline Vimenin & $15.18 \pm 4.11$ & $82.46 \pm 9.04$ & $\mathrm{t}=37.08$ & $<0.001$ \\
\hline Troponin & $1.23 \pm 0.71$ & $71.68 \pm 9.17$ & Mann Whitney $=6.65$ & $<0.001$ \\
\hline
\end{tabular}




\section{Results of cardiac alpha tropomyosin immunofluorescence staining:}

The cardiomyocytes showed positive staining with cardiac alpha tropomyosin on the $7^{\text {th }}$ and $8^{\text {th }}$ day post induction "Fig 18".

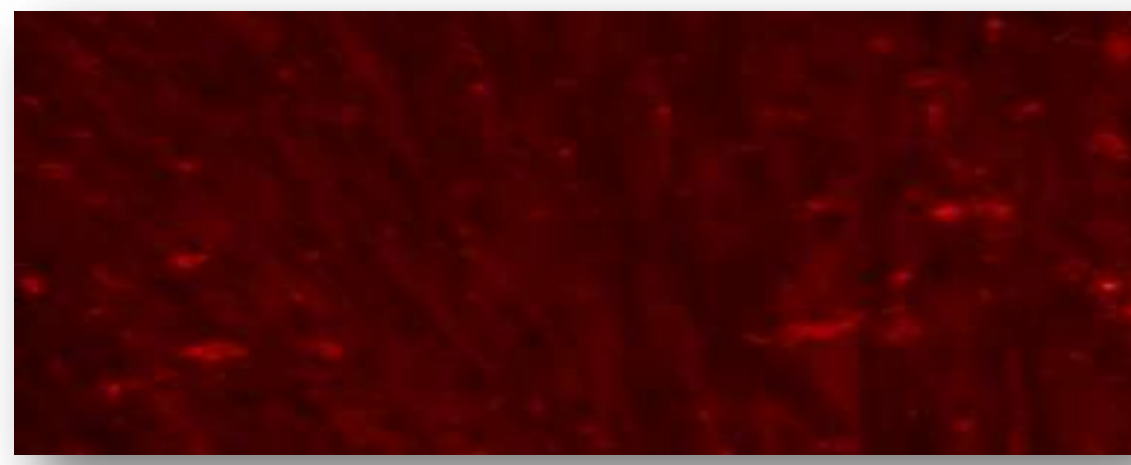

Fig 18: Immunofluorescent microscope image $x 40$ cardiomyocytes stained by cardiac alpha tropomyosin, on the 8 th day post induction.

\subsection{Proliferation curve and cell cycle activity in induced MSCs}

-The total number of MSCs and cardiomyocytes cultured at day 3 showed no significant statistical correlation (P value <0.001). A significant statistical correlation ( $\mathrm{P}$ value $<\mathbf{0 . 0 5}$ ) is found between MSCs with IGF-1 and MSCs. A highly significant statistical correlation $(\mathrm{P}$ value $\mathbf{< 0 . 0 0 1})$ is found between MSCs with IGF-1 and cardiomyocytes"table 3" .

-The total number of cells in MSCs, MSCs with IGF-1 and cardiomyocytes cultured at day6, 9 and 12 showed highly significant statistical correlation $(\mathrm{P}$ value $\leq 0.001)$. Regarding the growth pattern: the growth of cardiomyocytes cells showed a plateau pattern, while the growth of MSCs, MSCs with IGF-1 cells showed a linear pattern "Fig 19".

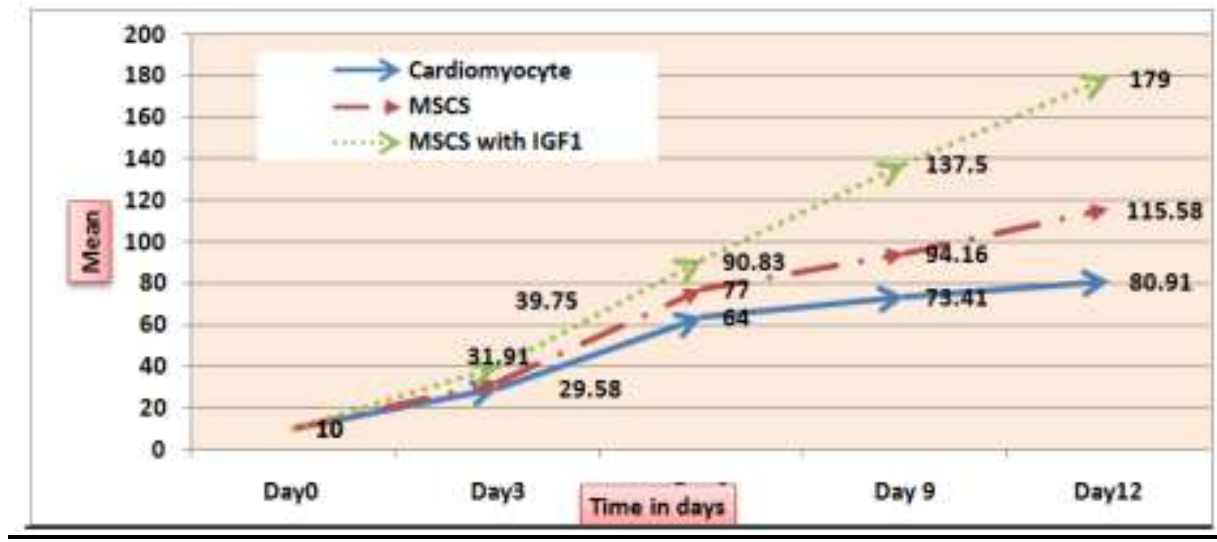

Fig 19: Proliferation curve for MSCs, MSCs with IGF1 and cardiomyocytes.

Table 3: Proliferation curve for MSCs, MSCs with IGF1 and cardiomyocytes.

\begin{tabular}{|c|c|c|c|c|c|}
\hline & \multicolumn{3}{|c|}{ Groups } & \multirow{3}{*}{$\begin{array}{c}\text { Test of } \\
\text { significance }\end{array}$} & \multirow{3}{*}{$P$ value } \\
\hline & $\begin{array}{r}\text { Cardiomyocyte }^{(1)} \\
(n=12)\end{array}$ & $\begin{array}{c}\text { MSCS }^{(2)} \\
(n=12)\end{array}$ & $\begin{array}{c}\text { MSCS with IGF1 }^{(3)} \\
(n=12)\end{array}$ & & \\
\hline & Mean \pm SD & Mean \pm SD & Mean \pm SD & & \\
\hline Day0 & $10.0 \pm 0.0$ & $10.0 \pm 0.0$ & $10.0 \pm 0.0$ & - & - \\
\hline Day3 & $29.58 \pm 6.30$ & $31.91 \pm 5.74$ & $39.75 \pm 5.65$ & $\begin{array}{l}F=9.74 \\
(<0.001)\end{array}$ & $\begin{array}{l}1 \text { vs. } 2=0.340 \\
1 \text { vs. } 3<0.001 \\
2 \text { vs. } 3=0.003\end{array}$ \\
\hline Day6 & $64.0 \pm 8.83$ & $77.0 \pm 7.53$ & $90.83 \pm 7.03$ & $\begin{array}{l}\mathrm{F}=35.20 \\
(<0.001)\end{array}$ & $\begin{array}{c}\text { 1vs.2, 1vs.3, 2vs.3 } \\
<0.001\end{array}$ \\
\hline Day 9 & $73.41 \pm 9.66$ & $94.16 \pm 5.16$ & $137.50 \pm 16.73$ & $\begin{array}{l}\mathrm{F}=96.23 \\
(<0.001)\end{array}$ & $\begin{array}{c}\text { 1vs.2, 1vs.3, } 2 \text { vs.3 } \\
<0.001\end{array}$ \\
\hline Day12 & $80.91 \pm 8.81$ & $115.58 \pm 10.71$ & $179.0 \pm 21.94$ & $\begin{array}{l}\mathrm{F}=132.10 \\
(<0.001)\end{array}$ & $\begin{array}{c}\text { 1vs.2, 1vs.3, 2vs.3 } \\
<0.001\end{array}$ \\
\hline
\end{tabular}




\section{Discussion}

Cardiomyocytes are known to stop regeneration after birth but there response to mitotic signals is by hypertrophy of the cells [17] rather than hyperplasia. When cardiomyocytes are lost, regional contractile dysfunction occur, and necrotized cardiac cells in infarcted cardiac tissues are replaced by fibroblasts progressively leading to scar tissue formation [18].Thus stem cell transplantation could be one of the best available life regenerative therapy for patients who suffer MI [19].The pluripotent properties of MSCs makes them an attractive therapeutic approach. The percentage of bone marrow MSC in adult is very small, approximately $0.001 \%-0.01 \%$ of cells isolated by Ficoll $(1.073 \mathrm{~g} / \mathrm{ml})$ density interface adhere to the bottom of the flask. Therefore, the isolation and expansion of human MSCs in vitro is very important. Wakitani had modified a method for cells isolation from rats adult bone marrow. In our study bone-marrow-derived stem cells were preferred because they are easy to gain and it had been proved that their transplantation leads to improvement of cardiac function and reduces the occurrence of major adverse cardiovascular events [20,29].

Lin et al. reported that bone marrow contains also endothelial progenitor cells (EPCs) which play an important role in angiogenesis[14]. It had been shown that erythropoietin improves cardiac function by homing and incorporating EPCs into the myocardial microvasculature and myocardial secretion of angiogenic factors. [15] Bone marrow cells were also able to migrate into skeletal and cardiac muscle and they are able to differentiate into cardiomyocytes. Such a process may contribute to regeneration or maintenance of tissue [21]. Differentiation of MSCs derived from bone marrow into cardiomyocytes can be achieved with 5-azacytidine, which is a chemical analogue of cytosine nucleoside. Others have reported that 5-azacytidine induces the differentiation of MSCs obtained from murine into cardiomyocytes [16, 23-25].

Xu et al., have shown that human BMMSCs could be isolated and used for repairing damaged heart[24]. This was in accordance with Liu et al., work which was done on rats [22]. Other reports have demonstrated that rat and mouse bone marrow cells have the ability to regenerate infarcted myocardium [26-28].Contrary to this and earlier reports [25, 29]. Liu and colleagues reported that rat MSCs could not be expanded and induced to differentiate into cardiomyocytes by 5-azacytidine treatment[22].In this regard, the methods for isolation and culture conditions may be very important. In our study the media used was DMEM containing 10\% FBS which was optimal for the expansion of MSCs and the expression of the myogenic properties. bFGF and IGF-1 were included in our culture medium . It had been reported that bFGF could increase the myogenic phenotype expression and enhance myotubes formation [29]. This was explained by a synergistic action between both 5azacytidine and bFGF during differentiation. The dose of Azacytidine used in our study was $10 \mathrm{~mm}$ which was the dose in which differentiation occurs without death of the cells[23,27].

The mechanism by which 5-aza promotes cardio myogenic differentiation remains unclear. The effect of 5azacytidine on the expression of protein bone marrow MSCs obtained from porcine origin in vitro using proteomics techniques have been studied .They concluded up-regulation in the proteins which play a role in cell proliferation and differentiation, such as cardiac alpha tropomyocin [30]. The details of 5-azacytidine signaling mechanisms still remain unexplained[31]. It had been reported that GSK-3 $\alpha$ and GSK-3 $\beta$ help in mediating the differentiation of cardiomyocyte in murine BMSCs. While GSK-3 $\beta$ enhances the differentiation of cardiomyocyte from MSCs by $\beta$-catenin down regulation, whereas GSK-3 $\alpha$ inhibits the differentiation of cardiomyocyte from MSCs through c-Jun down regulation [32]. It had also been reported that the ERK signaling pathway promotes the cardiomyocytes development obtained from embryonic stem cells[33]. It had been found that ERK phosphorylation is increased in a cardiomyogenic cell line from BMSCs of murine origin after it had been exposed to 5-azacytidine and stimulated with phenylephrine[34].

In our study the cells were positive for cardiac troponinT which was in accordance with[13]. It had been reported that Cardiac troponin $\mathrm{T}$ is the earliest marker of myogenic differentiation[40]. It is essential for myofibrillar ATPase activity and is expressed in the heart of human and required for contractility of muscle [35]. The cells shows positive expression of Vimentin which was in accordance with[24, 36]. Tropomyosin in our study was also positive, this was in accordance with[37].

Regarding the proliferation curve proliferation increased after addition of IGF-1whichwas in accordance with HUANG et al who hypothesized that IGF-1 may play an important role in proliferation, migration, and differentiation of MSCs during transplantation. [40]Contrary to this Li et al. observed that MSCs cultured in vitro with IGF-1 at final concentrations of $2.5,5.0$ and $10.0 \mathrm{ng} / \mathrm{ml}$ for $48 \mathrm{~h}$ did not affect the rate of proliferation. Therefore, whether this result was due to inadequate concentrations of IGF-1 or the culture time was too short needs to be further investigated[38]. In terms of the differentiation it has been proved that MSCs can be differentiated into cardiomyocytes s by a combination of, vascular endothelial growth factor (VEGF), IGF-1 and basic fibroblast growth factor (bFGF) [39]. 


\section{Conclusion}

Our results indicate that Mesenchymal stem cells obtained from human bone marrow of adult human can be differentiated in vitro into cardiomyocytes. The prevailing evidence suggests that bone marrow stem cells can regenerate myogenic cells in cardiac tissue. These can help damaged cardiac tissues repairing by adult human bone marrow MSCs administration.

\section{Acknowledgments}

We acknowledge our Menoufia university laboratory, including stuff collaborators, technical help, and secretarial assistance. The source of funding are the authors.

\section{References}

[1] Friedenstein AJ, Chailakhyan RK, Latsinik NV, Panasyuk AF,Keiliss-Borok IV.Stromal cells responsible for transferring the microenvironment of the hemopoietic tissues. Cloning in vitro and retransplantation in vivo. Transplantation 1974; 17:331-340.

[2] Pittenger MF, Mackay AM, Beck SC, Jaiswal RK, Douglas R, Mosca JD, Moorman MA, Simonetti DW, Craig S, Marshak DR Multilineage potential of adult human mesenchymal stem cells. Science 1999; 284:143-147.

[3] Souza Neto JL, Araujo FI, Rego AC, Dominici VA, Azevedo IM, Egito ES, Brandao-Neto J, Medeiros AC. Effects of simvastatin in abdominal sepsis in rats. Acta Cir Bras 2006; 21:8-12.

[4] Minguell J., Erices A., and Conget P., "Mesenchymal stem cells," Experimental Biology and Medicine 2001; 226:507-520.

[5] Park K. S., Lee Y. S., and Kang K. S., "In vitro neuronal and osteogenic differentiation of mesenchymal stem cells from human umbilical cord blood," Journal of Veterinary Science 2006 ; 7: 343-348.

[6] Lee K. D., Kuo T. K. C., Whang-Peng J., and Chung Y. F., "In vitro hepatic differentiation of human mesenchymal stemcells," Hepatology 2004 ; 40: 1275-1284.

[7] Beltrami AP, Barlucchi L, Torella D, Baker M, Limana F, Chimenti S, Kasahara H, Rota M, Musso E, Urbanek K, Leri A, Kajstura J,Nadal-Ginard B, Anversa P. Adult Cardiac Stem Cells Are Multipotent and Support Myocardial Regeneration Cell 2003; 114: $763-776$.

[8] Potdar P. D. and Prasannan P. Differentiation of Human Dermal Mesenchymal Stem Cells into Cardiomyocytes by Treatment with 5 Azacytidine: Concept for Regenerative Therapy in Myocardial Infarction 2013. Hindawi Publishing Corporation ISRN Stem Cells Volume, Article ID 687282, 9 pages.

[9] Yoon Y. S., Lee N., and Scadova H. "Myocardial regeneration with bone-marrow-derived stem cells," Biology of the Cell 2005; 97: 253-263.

[10] Li RK, Mickle DA, Weisel RD, Mohabeer MK, Zhang J, Rao V, Li G, Merante F, Jia ZQ. Natural history of fetal rat cardiomyocytes transplanted into adult rat myocardial scar tissue. Circulation 1997;96:179-186.

[11] Van Laake LW, Hassink R, Doevendans PA and Mummery C. Heart repair and stem cells. J Physiol 2006; 577:467-478.

[12] Phinney DG, Prockop DJ. Concise review: Mesenchymal stem/multipotent stromal cells: The state of transdifferentiation and modes of tissue repair-Current views. STEM CELLS 2007; 25:2896-2902.

[13] Gonzalez-Garza MT, Alcaraz C, Gonzalez-Jara L Arcos D,Moreno Cuevas J E.Engraftment of pre-differentiated stem cells into cardiomyocytes in an animal model of ischemic cardiopathy 2014;4:1-7 .

[14] Lin Y., Weisdorf D. J., Solovey A., and Hebbel R. P., "Origins of circulating endothelial cells and endothelial outgrowth from blood," The Journal of Clinical Investigation 2000; 105:71-77.

[15] Westenbrink B. D., Lipšic E., Meer P. Harst P, Oeseburg H, Sarvaas GD, KosterJ, Voors A A., Veldhuisen D.J., Gilst W. H. , . Schoemaker R G "Erythropoietin improves cardiac function through endothelial progenitor cell and vascular endothelial growth factor mediated neovascularization," European Heart Journal 2007; 28: 2018-2027,

[16] Shi M., Liu Z. W., and Wang F. S., "Immunomodulatory properties and therapeutic application of Mesenchymal stem cells," Clinical and Experimental Immunology2011; 164:1-8,.

[17] Kodama H, Fukuda K, Pan J, Makino S, Baba A, Hori S, Ogawa S.. Leukemia inhibitory factor, a potent cardiac hypertrophic cytokine, activates the JAK/STAT pathway in rat cardiomyocytes. Circ1997; 81:656-663.

[18] Leor, J., Patterson, M., Quinones, M.J., Kedes, L.H., and Kloner, R.A. Transplantation of fetal myocardial tissue into the infarcted myocardium of rat. A potential method for repair of infarcted myocardium?Circulation 1996;94:332-336.

[19] Nugent H. M. and. Edelman E. R, "Tissue engineering therapy for cardiovascular disease," Circulation Research 2003; 92: 10681078 .

[20] Assmus B , Rolf A, Erbs S, Elsässer A, Haberbosch W, Hambrecht R, Tillmanns H, Yu J, Corti R, Mathey DG, Hamm CW, Süselbeck T, Tonn T, Dimmeler S, Dill T, Zeiher AM, Schächinger V; REPAIR-AMI Investigators. "Clinical outcome 2 years after intracoronary administration of bone marrow-derived progenitor cells in acute myocardial infarction," Circulation 2010; 3: 8996.

[21] Orlic D. Adult bone marrow stem cells regenerate myocardium in ischemic heart disease. Ann N Y Acad Sci 2003;996:152-157,

[22] Liu Y., Song J., Liu W., Wan Y., Chen X., and Hu C., "Growth and differentiation of rat bone marrow stromal cells: does 5azacytidine trigger their cardiomyogenic differentiation?” Cardiovascular Research 2003 ; 58: 460-468.

[23] Antonitsis P., Ioannidou-Papagiannaki E., Kaidoglou A., and Papakonstantinou C., "In vitro cardiomyogenic differentiation of adult human bone marrow mesenchymal stem cells. The role of 5-azacytidine," Interactive Cardiovascular and Thoracic Surgery 2007 ; 6: 593-597.

[24] Xu W, Zhang X, Qian H, ZHU W, SUN X, HU J, ZHOU H, AND CHEN Y . "Mesenchymal stem cells from adult human bone marrow differentiate into a cardiomyocyte phenotype in vitro," Experimental Biology and Medicine 2004; 229 : 623-631.

[25] Makino S, Fukuda K, Miyoshi S, Konishi F, Kodama H, Pan J, Sano M, Takahashi T, Hori S, Abe H, Hata J, Umezawa A, Ogawa S. Cardiomyocytes can be generated from marrow stromal cells in vitro. J Clin Invest 1999;103:697-705.

[26] Jackson KA, Majka SM, Wang H, Pocius J, Hartley CJ, Majesky MW, Entman ML, Michael LH, Hirschi KK, Goodell MA. Regeneration of ischemic cardiac muscle and vascular endothelium by adult stem cells. J Clin Invest 2001;107:1395-1402 .

[27] Tomita S, Li RK, Weisel RD, Mickle DA, Kim EJ, Sakai T, Jia ZQ. Autologous transplantation bone marrow cells improves damaged heart function. Circulation 1999;100:247-256.

[28] Gojo S, Gojo N, Takeda Y, Mori T, Abe H, Kyo S, Hata J, Umezawa A. In vivo cardiovasculogenesis by direct injection of isolated adult mesenchymal stem cells. Exp Cell Res 2003;288:51-59. 
[29] Wakitani S, Saito T, Caplan AI. Myogenic cells derived from rat bone marrow mesenchymal stem cells exposed to 5-azacytidine. Muscle Nerve 1995;18:1417-1426.

[30] Ye NS, Zhang RL, Zhao YF, Feng X, Wang YM, Luo GA. Effect of 5- azacytidine on the protein expression of porcine bone marrow mesenchymal stem cells in vitro. Geno Prot Bioinfo 2006; 4:18-25.

[31] Barry F. P. and Murphy J. M., "Mesenchymal stem cells: clinical applications and biological characterization," The International Journal of Biochemistry \& Cell Biology 2004: 36: 568-584.

[32] Cho J. Rameshwar P. Sadoshima J. Distinct roles of glycogen synthase kinase (GSK)-3alpha and GSK-3 $\beta$ in mediating cardiomyocyte differentiation in murine bone marrow-derived mesenchymal stem cells. J Biol Chem 2009; 284:36647-36658.

[33] Kim HS. Cho JW. Hidaka K. Morisaki T. Activation of MEK-ERK by heregulin-b1 promotes the development of cardiomyocytes derived from ES cells. Biochem Biophys Res Commun 2007; 361:732-738.

[34] Fukuda K. Regeneration of cardiomyocytes from bone marrow: use of mesenchymal stem cell for cardiovascular tissue engineering. Cytotechnology. 2003; 41:165-175.

[35] Zot A.S. and Potter J. D., "Structural aspects of troponin tropomyosin regulation of skeletal muscle contraction," Annual Review of Biophysics and Biophysical Chemistry1987; 16: 535-559.

[36] Robert a. Rose,a,b huijie jiang,c xinghua wang,c simone helke,c james n. Tsoporis,d nanling gong,a,b stephanie c.j. Keating,c thomas g. Parker,d peter h. Backx,a,b armand keatingb,c bone marrow-derived mesenchymal stromal cells express cardiac-specific markers, retain the stromal phenotype, and do not become functional cardiomyocytes in vitro stem cells 2008;26:2884-2892.

[37] Spray J, Campos de Carvalho A, and Mendez-Otero R. Chemical Induction of Cardiac Differentiation in P19 Embryonal Carcinoma Stem Cells Stem Cells Dev. 2010 Mar; 19(3): 403-411.

[38] Li, y., yu, x., lin, s., li, x., zhang, s., song, y.h.,. Insulin-like growth factor 1 enhances the migratory capacity of mesenchymal stem cells. Biochem. Biophys. Res commun 2007; 356:780-784.

[39] Muguruma Y, Reyes M, Nakamura Y, Sato T, Matsuzawa H, Miyatake H, Akatsuka A, Itoh J, Yahata T, Ando K, Kato S, Hotta T. In vivo and in vitro differentiation of myocytes from human bone marrow-derived multipotent progenitor cells. Exp. Hematol 2003; 31:1323-1330.

[40] Huang YL, Qiu RF Mai WY, Kuang J, Cai XY, Dong Y, Hu Y, Song Y, Cai A, and Jiang Z .Effects of insulin-like growth factor-1 on the properties of mesenchymal stem cells in vitro* (biomed \& biotechnol) 2012; 13:20-28. 